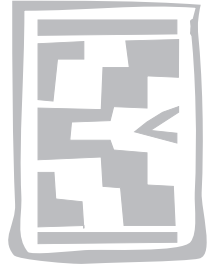

\title{
Hosts, seasonality and geographic distribution of the South African tortoise tick, Amblyomma
} marmoreum

I.G. HORAK ${ }^{1}$, I.J. MCKAY', ${ }^{2}$ HELOISE HEYNE ${ }^{2}$ and A.M. SPICKETT ${ }^{2}$

\begin{abstract}
HORAK, I.G., MCKAY, I.J., HEYNE, HELOISE \& SPICKETT, A.M. 2006. Hosts, seasonality and geographic distribution of the South African tortoise tick, Amblyomma marmoreum. Onderstepoort Journal of Veterinary Research, 74:13-25

The tortoise tick Amblyomma marmoreum was collected from large numbers of reptiles and other animals during the course of numerous surveys conducted in South Africa. A total of 1229 ticks, of which 550 were adults, were recovered from 309 reptiles belonging to 13 species, with leopard tortoises, Geochelone pardalis being the most heavily infested. The 269 birds sampled harboured 4901 larvae, 217 nymphs and no adult ticks, and the prevalence of infestation was greatest on helmeted guineafowls, Numida meleagris. Only two larvae were recovered from 610 rodents, including 31 spring hares, Pedetes capensis, whereas 1144 other small mammals yielded 1835 immature ticks, of which 1655 were collected from 623 scrub hares, Lepus saxatilis. The 213 carnivores examined harboured 2459 ticks of which none were adult. A single adult tick and 6684 larvae and 62 nymphs were recovered from 656 large herbivores, and a total of 4081 immature ticks and three adults were collected from 1543 domestic animals and 194 humans.
\end{abstract}

Adult male and female $A$. marmoreum were most numerous on reptiles during January and February, and larvae during March. The largest numbers of larvae were present on domestic cattle and helmeted guineafowls in the Eastern Cape Province during March or April respectively, whereas larvae were most numerous on helmeted guineafowls, scrub hares and the vegetation in north-eastern Mpumalanga Province during May. In both provinces nymphs were most numerous between October and December. Amblyomma marmoreum appears to be most prevalent in the western regions of the Western and Eastern Cape and Free State provinces, and the north-eastern regions of the Northern Cape, KwaZuluNatal, Mpumulanga and Limpopo provinces.

Keywords: Amblyomma marmoreum, birds, carnivores, domestic animals, geographic distribution, large herbivores, reptiles, seasonality, small mammals, vegetation

\section{INTRODUCTION}

The majority of ticks that have been collected from tortoises in South Africa belong to the genus Ambly-

1 Department of Veterinary Tropical Diseases, Faculty of Veterinary Science, University of Pretoria, Onderstepoort, 0110 South Africa, and Department of Zoology and Entomology, University of the Free State, Bloemfontein, 9301 South Africa

2 Department of Parasitology, ARC-Onderstepoort Veterinary Institute, Onderstepoort, 0110 South Africa

* Present address: School of Geosciences, University of Witwatersrand, Private Bag X3, Wits, 2050 South Africa

Accepted for publication 22 June 2005-Editor omma and of these Amblyomma marmoreum, colloquially known as the South African tortoise tick, is probably the most prevalent (Theiler \& Salisbury 1959). Although records of ticks on tortoises in South Africa date back to the $18^{\text {th }}$ and $19^{\text {th }}$ centuries (Theiler 1943; Walker \& Schulz 1984), it was not until Theiler \& Salisbury (1959) and Norval (1975) published their descriptions of ticks in the "Amblyomma marmoreum group" and on the ecology of $A$. marmoreum, respectively, that the taxonomy and biology of the latter tick was comprehensively addressed. In their paper, Theiler \& Salisbury (1959) illustrated and described all stages of development of $A$. marmoreum 
and mapped its distribution and supplied a brief host list, while Norval (1975) described its ecology, life cycle and seasonality in the Eastern Cape Province and provided a more comprehensive list of hosts. Some years later Walker \& Schulz (1984) recorded the burdens of $A$. marmoreum on tortoises in the Addo Elephant National Park in the Eastern Cape Province, while Norval (1983) listed its hosts and mapped its distribution in Zimbabwe.

Interest in $A$. marmoreum gained momentum with the unpublished discovery by Bezuidenhout \& Olivier in 1985 and Bezuidenhout in 1986 (cited by Bezuidenhout 1987, and Oberem \& Bezuidenhout 1987 ) that it could both acquire and transmit Ehrlichia (Cowdria) ruminantium, the causative organism of heartwater in domestic and wild ruminants. In addition, Bezuidenhout (1988) demonstrated that the leopard tortoise, a preferred host of all stages of development of the tick, could be infected with $E$. (Cowdria) ruminantium and that the tick could acquire infection from an infected tortoise. He also demonstrated that two hosts of the immature stages, namely helmeted guineafowls and scrub hares could act as subclinical reservoirs of E. (Cowdria) ruminantium.

Walker \& Olwage (1987) have published colour illustrations of a male and female tick and have mapped the distribution of $A$. marmoreum in Africa. Horak, Maclvor, Petney \& De Vos (1987a) have provided host lists as well as the mean intensity and prevalence of infestation on these hosts, while Dower, Petney \& Horak (1988) determined the tick burdens, and the detachment periods and weights of the various life stages of $A$. marmoreum on naturally infested tortoises in the Eastern Cape Province. The presence, and occasionally also the seasonality, of the immature stages of $A$. marmoreum on a large number of host species have been recorded by Horak and his co-workers in several published and unpublished surveys of parasites of domestic and wild animals conducted in South Africa (Horak \& Fourie 1986; Horak, Jacot Guillarmod, Moolman \& De Vos 1987b; Dower et al. 1988; Fourie \& Horak 1990; Horak, Williams \& Van Schalkwyk 1991a; Horak, Fourie, Novellie \& Williams 1991b; Horak, Spickett, Braack \& Williams 1991c; Horak, Knight \& Williams 1991d; Horak \& Fourie 1991; Horak, Boomker, Spickett \& De Vos 1992; Horak, Spickett, Braack \& Penzhorn 1993; Boomker, Horak \& Ramsay 1994; Horak \& Boomker 1998; Horak 1999; Horak, Braack, Fourie \& Walker 2000; Horak, Maclvor \& Greeff 2001; Horak, Gallivan, Braack, Boomker \& De Vos 2003; Horak \& Matthee 2003; Uys \& Horak 2005).
Fielden, Magano \& Rechav (1992) have compared the length of the life cycle of $A$. marmoreum on tortoises and on guinea pigs in the laboratory, and Fielden \& Rechav (1994) and Rechav \& Fielden (1995) have determined its attachment sites and seasonal abundance on leopard tortoises. Burridge (2001) and Burridge \& Simmons (2003) have described its introduction as well as that of other ticks into the United States of America on imported reptiles and Allan, Simmons \& Burridge (1998) have reported its establishment on a reptile-breeding facility in Florida. Peter, Burridge \& Mahan (2000) have demonstrated the competence of $A$. marmoreum as a potential effective vector of $E$. (Cowdria) ruminantium in that country.

The present paper is based on the findings pertinent to $A$. marmoreum in the numerous surveys conducted in South Africa as well as on a large number of tick collections made from reptiles, particularly tortoises that have not previously been published. Its purpose is to record the presence and the seasonality of adult and immature A. marmoreum on tortoises, and that of its larvae and nymphs on mammals and birds as well as of its free-living larvae on vegetation. Furthermore the coordinates of the localities at which the abovementioned collections were made have been used to up-date Theiler \& Salisbury's (1959) map of the tick's distribution in South Africa.

\section{MATERIALS AND METHODS}

Ticks were collected manually from several live reptiles, chiefly tortoises, and preserved in $70 \%$ ethyl alcohol for subsequent identification and counting. Ticks were also collected from domestic and wild animals in various regions of the country, as well as from the vegetation within the Kruger National Park in north-eastern Mpumalanga Province. The techniques used to collect ticks in the various surveys have been described by Horak et al. (1987b; 1991c; 1992), Dower et al. (1988) and Spickett, Horak, Van Niekerk \& Braack (1992), and are not repeated here. The findings presented pertain only to $A$. marmoreum and not to the other ticks collected during the various surveys.

The animal species sampled have been divided into six groupings, namely reptiles, birds, small mammals, carnivores, large herbivores, and domestic animals and humans, and the numbers of $A$. marmoreum collected from each host species within each of the groupings have been summarized in tabular format. The scientific names of the animals 
examined are included in the tables and are not repeated in the text.

The monthly mean adult and immature tick burdens of all tortoises examined over a period 6 years, irrespective of species and the year in which they were sampled, have been used to construct a pattern of annual seasonality for $A$. marmoreum. A similar process has been followed with the immature tick burdens of helmeted guineafowls and of cattle examined at monthly intervals over a period of 2 years in the Eastern Cape Province, and of helmeted guineafowls and scrub hares examined at monthly intervals over periods of 2 and 6 years, respectively in north-eastern Mpumalanga Province. The seasonality of free-living larvae on the vegetation was determined from the means of consecutive monthly collections made over a period of 13 years and 8 months in a landscape zone within the southern Kruger National Park.

The geographic coordinates of the localities at which the various collections were made have been added to those of Theiler \& Salisbury (1959), and have been used to redefine the distribution of $A$. marmoreum within the borders of South Africa.

\section{RESULTS AND DISCUSSION}

\section{Hosts}

A total of 309 reptiles belonging to 13 species were examined and with the exception of the Karoo padloper, of which only two specimens were sampled, all tortoise species were infested with adult $A$. marmoreum (Table 1). The largest numbers of adult and immature ticks were recovered from leopard tortoises. Comparisons between reptile species are, however, not possible because of differences in the sampling techniques. Most collections were done manually and focused on the more visible and hence detachable ticks, but 14 leopard tortoises were kept in cages over water until all the ticks present on most of them had detached (Dower et al. 1988). The prevalence of infestation on the various species of reptiles can also not be deduced from the available data as the majority of collections were made from live animals and no records were kept of the number of reptiles on which no ticks were seen.

Whereas other animals harbour only the immature stages of $A$. marmoreum, reptiles, and more particularly tortoises, harbour all stages of development. This pattern of host preference dictates that the tick's life cycle can be completed only in those localities where tortoises and certain other large reptile species are present. In the present study the ratio of larvae to nymphs to adults on tortoises and other reptiles was 2.7:1.0:3.0, indicating that the number of immature ticks would have been unable to maintain the adult population. However, as most of the collections made from these animals were not designed to be total recoveries, and focused mainly on the more visible adult ticks, these ratios are not surprising. In a more detailed study on the seasonal occurrence of $A$. marmoreum, leopard tortoises in a large, fenced enclosure containing natural savannatype vegetation in the National Zoological Gardens, Pretoria, were examined for ticks at monthly intervals (Rechav \& Fielden 1995). Over a period of a year the ratio of larvae to nymphs to adults on these animals was 5.7:2.7:1.0, indicating an adequate number of immature ticks to maintain the adult burdens on the tortoises.

Five bird species, comprising 269 individuals, were examined for ticks (Table 2). These examinations were thorough as they were conducted on dead birds and hence both the prevalence and intensity of infestation recorded are more reliable than they would have been had they been based on manual collections of ticks from live birds. A large proportion of helmeted guineafowls and francolins were infested and many larvae were collected from these birds. The largest number of ticks recovered from a single guineafowl consisted of 585 larvae and one nymph collected from a bird examined during February 1984 in the Mountain Zebra National Park in the Eastern Cape Province. Helmeted guineafowls and francolins are not only large birds, but also spend most of their lives on the ground, factors that both probably contribute to their success as hosts of the immature stages of $A$. marmoreum.

Ticks were collected from a total of 1754 small mammals belonging to 11 species, the majority of which were killed for survey purposes (Table 3). Amongst these there were 579 murid rodents and 31 springhares, a very large rodent, all of which were sampled in localities in which tortoises, or other animals harboured $A$. marmoreum, and yet only two bush Karoo rats were infested, each with a single larva. This supports the contention of Petney, Horak, Howell \& Meyer (2004) that rodents are not good hosts of Amblyomma spp. They arrived at this conclusion after recovering only five unhealthy-looking larvae and a nymph of Amblyomma hebraeum from just six of 169 collections made from striped grass mice in a habitat heavily contaminated with 
South African tortoise tick, Amblyomma marmoreum

TABLE 1 Amblyomma marmoreum collected from reptiles

\begin{tabular}{|c|c|c|c|c|c|c|c|}
\hline \multirow{2}{*}{ Host species } & \multirow{2}{*}{$\begin{array}{l}\text { Number } \\
\text { examined }\end{array}$} & \multirow{2}{*}{$\begin{array}{l}\text { Number } \\
\text { infested }\end{array}$} & \multicolumn{5}{|c|}{ Number of ticks collected } \\
\hline & & & Larvae & Nymphs & Males & Females & Total \\
\hline $\begin{array}{l}\text { Leopard tortoise, } \\
\text { Geochelone pardalis }\end{array}$ & 59 & 56 & 336 & 92 & 301 & 83 & 812 \\
\hline $\begin{array}{l}\text { Geometric tortoise, } \\
\text { Psammobates geometricus }\end{array}$ & 64 & 54 & 9 & 7 & 52 & 12 & 80 \\
\hline $\begin{array}{l}\text { Karoo tortoise, } \\
\text { Psammobates oculifer }\end{array}$ & 11 & 11 & 0 & 1 & 9 & 4 & 14 \\
\hline $\begin{array}{l}\text { Tent tortoise, } \\
\text { Psammobates tentorius } \\
\text { tentorius }\end{array}$ & 24 & 11 & 8 & 8 & 14 & 2 & 32 \\
\hline $\begin{array}{l}\text { Tent tortoise, } \\
\text { Psammobates tentorius } \\
\text { trimeni }\end{array}$ & 5 & 1 & 0 & 0 & 1 & 0 & 1 \\
\hline $\begin{array}{l}\text { Angulate tortoise, } \\
\text { Chersina angulata }\end{array}$ & 52 & 6 & 0 & 5 & 12 & 1 & 18 \\
\hline $\begin{array}{l}\text { Areolate padloper, } \\
\text { Homopus areolatus }\end{array}$ & 73 & 68 & 58 & 63 & 32 & 20 & 173 \\
\hline $\begin{array}{l}\text { Speckled padloper, } \\
\text { Homopus signatus }\end{array}$ & 11 & 2 & 81 & 0 & 1 & 0 & 82 \\
\hline $\begin{array}{l}\text { Greater padloper, } \\
\text { Homopus femoralis }\end{array}$ & 4 & 4 & 0 & 1 & 4 & 0 & 5 \\
\hline $\begin{array}{l}\text { Karoo padloper, } \\
\text { Homopus boulengeri }\end{array}$ & 2 & 2 & 2 & 5 & 0 & 0 & 7 \\
\hline $\begin{array}{l}\text { White-throated monitor, } \\
\text { Varanus exanthematicus }\end{array}$ & 1 & 1 & 0 & 1 & 1 & 0 & 2 \\
\hline Puff adder, Bitis arietans & 2 & 1 & 0 & 0 & 1 & 0 & 1 \\
\hline $\begin{array}{l}\text { Gaboon adder, } \\
\text { Bitis gabonica }\end{array}$ & 1 & 0 & 2 & 0 & 0 & 0 & 2 \\
\hline Total & 309 & 217 & 496 & 183 & 428 & 122 & 1229 \\
\hline
\end{tabular}

TABLE 2 Amblyomma marmoreum collected from birds

\begin{tabular}{|c|c|c|c|c|c|c|c|}
\hline \multirow{2}{*}{ Host species } & \multirow{2}{*}{$\begin{array}{l}\text { Number } \\
\text { examined }\end{array}$} & \multirow{2}{*}{$\begin{array}{l}\text { Number } \\
\text { infested }\end{array}$} & \multicolumn{5}{|c|}{ Number of ticks collected } \\
\hline & & & Larvae & Nymphs & Males & Females & Total \\
\hline $\begin{array}{l}\text { Helmeted guineafowl, } \\
\text { Numida meleagris }\end{array}$ & 231 & 177 & 4175 & 206 & 0 & 0 & 4381 \\
\hline $\begin{array}{l}\text { Greywing francolin, } \\
\text { Francolinus africanus }\end{array}$ & 7 & 4 & 129 & 0 & 0 & 0 & 129 \\
\hline $\begin{array}{l}\text { Cape francolin, } \\
\text { Francolinus capensis }\end{array}$ & 7 & 3 & 15 & 1 & 0 & 0 & 16 \\
\hline $\begin{array}{l}\text { Crested francolin, } \\
\text { Francolinus sephaena }\end{array}$ & 23 & 13 & 582 & 10 & 0 & 0 & 592 \\
\hline $\begin{array}{l}\text { Swainson's francolin, } \\
\text { Francolinus swainsonii }\end{array}$ & 1 & 0 & 0 & 0 & 0 & 0 & 0 \\
\hline Total & 269 & 197 & 4901 & 217 & 0 & 0 & 5118 \\
\hline
\end{tabular}


TABLE 3 Amblyomma marmoreum collected from small mammals

\begin{tabular}{|c|c|c|c|c|c|c|c|}
\hline \multirow{2}{*}{ Host species } & \multirow{2}{*}{$\begin{array}{l}\text { Number } \\
\text { examined }\end{array}$} & \multirow{2}{*}{$\begin{array}{l}\text { Number } \\
\text { infested }\end{array}$} & \multicolumn{5}{|c|}{ Number of ticks collected } \\
\hline & & & Larvae & Nymphs & Males & Females & Total \\
\hline $\begin{array}{l}\text { Pouched mouse, } \\
\text { Saccostomys campestris }\end{array}$ & 14 & 0 & 0 & 0 & 0 & 0 & 0 \\
\hline $\begin{array}{l}\text { Namaqua rock mouse, } \\
\text { Aethomys namaquensis }\end{array}$ & 425 & 0 & 0 & 0 & 0 & 0 & 0 \\
\hline $\begin{array}{l}\text { Striped grass mouse, } \\
\text { Rhabdomys pumilio }\end{array}$ & 91 & 0 & 0 & 0 & 0 & 0 & 0 \\
\hline $\begin{array}{l}\text { Swamp rat, } \\
\text { Otomys irroratus }\end{array}$ & 2 & 0 & 0 & 0 & 0 & 0 & 0 \\
\hline $\begin{array}{l}\text { Bush Karoo rat, } \\
\text { Otomys unisulcatus }\end{array}$ & 47 & 2 & 2 & 0 & 0 & 0 & 2 \\
\hline $\begin{array}{l}\text { Spring hare, } \\
\text { Pedetes capensis }\end{array}$ & 31 & 0 & 0 & 0 & 0 & 0 & 0 \\
\hline $\begin{array}{l}\text { Rock dassie, } \\
\text { Procavia capensis }\end{array}$ & 102 & 21 & 108 & 3 & 0 & 0 & 111 \\
\hline $\begin{array}{l}\text { Rock elephant shrew, } \\
\text { Elephantulus myurus }\end{array}$ & 296 & 7 & 10 & 1 & 0 & 0 & 11 \\
\hline $\begin{array}{l}\text { Cape hare, } \\
\text { Lepus capensis }\end{array}$ & 67 & 8 & 15 & 4 & 0 & 0 & 19 \\
\hline $\begin{array}{l}\text { Scrub hare, } \\
\text { Lepus saxatilis }\end{array}$ & 623 & 272 & 1260 & 395 & 0 & 0 & 1655 \\
\hline $\begin{array}{l}\text { Smith's red rock rabbit, } \\
\text { Pronolagus rupestris }\end{array}$ & 56 & 17 & 36 & 3 & 0 & 0 & 39 \\
\hline Total & 1754 & 327 & 1431 & 406 & 0 & 0 & 1837 \\
\hline
\end{tabular}

larvae of this tick. With the exception of scrub hares, of which $43.6 \%$ were infested with $A$. marmoreum, and which collectively also harboured surprisingly large numbers of nymphs, other small mammals also appeared not to be suitable hosts of this parasite.

Fifteen carnivore species, comprising 213 individuals that were killed for survey and other purposes, were examined. The prevalence of infestation was highest on black-backed jackals (Table 4).

The average prevalence of infestation on the 656 herbivores, all of which had been killed for survey purposes, was $28.2 \%$ and varied between $2.4 \%$ on 41 warthogs to $72.7 \%$ on 11 elands (Table 5). The only black wildebeest infested was a very old animal, which harboured a burden of 146 larvae and two nymphs, while 34 infested greater kudus had mean burdens of 92 larvae. With the exception of a single male tick on a bontebok ram examined during December 1979 in the Bontebok National Park in the Western Cape Province (Horak, Brown, Boomker, De Vos \& Van Zyl 1982), no large herbivorous animal was infested with adult ticks.

The ticks from domestic cats and dogs were collected either by the staff at veterinary clinics when the animals were brought in for treatment, or by their owners and hence cannot be regarded as complete collections or as a true indication of the prevalence of infestation on these animals. Those collected from horses, cattle, sheep and goats were recovered from animals that had been slaughtered for survey purposes and had thus been thoroughly processed for the recovery of external and internal parasites. The ticks recorded on humans were collected as part of an on-going survey to identify those species that bite people in South Africa (Horak, Fourie, Heyne, Walker \& Needham 2002).

The incomplete nature of the collections made from dogs and cats is endorsed by the fact that larger numbers of nymphs than larvae were recovered, whereas on the other domestic animals, for which 
TABLE 4 Amblyomma marmoreum collected from carnivores

\begin{tabular}{|c|c|c|c|c|c|c|c|}
\hline \multirow{2}{*}{ Host species } & \multirow{2}{*}{$\begin{array}{l}\text { Number } \\
\text { examined }\end{array}$} & \multirow{2}{*}{$\begin{array}{l}\text { Number } \\
\text { infested }\end{array}$} & \multicolumn{5}{|c|}{ Number of ticks collected } \\
\hline & & & Larvae & Nymphs & Males & Females & Total \\
\hline $\begin{array}{l}\text { Black-backed jackal, } \\
\text { Canis mesomelas }\end{array}$ & 8 & 8 & 243 & 27 & 0 & 0 & 270 \\
\hline $\begin{array}{l}\text { Hunting dog, } \\
\text { Lycaon pictus }\end{array}$ & 8 & 1 & 0 & 16 & 0 & 0 & 16 \\
\hline $\begin{array}{l}\text { Bat-eared fox, } \\
\text { Otocyon megalotis }\end{array}$ & 2 & 1 & 1 & 0 & 0 & 0 & 1 \\
\hline $\begin{array}{l}\text { Cheetah, } \\
\text { Acinonyx jubatus }\end{array}$ & 3 & 2 & 26 & 18 & 0 & 0 & 44 \\
\hline Caracal, Caracal caracal & 51 & 35 & 1360 & 15 & 0 & 0 & 1375 \\
\hline $\begin{array}{l}\text { African wild cat, } \\
\text { Felis lybica }\end{array}$ & 1 & 1 & 1 & 0 & 0 & 0 & 1 \\
\hline Lion, Panthera leo & 24 & 17 & 159 & 203 & 0 & 0 & 362 \\
\hline $\begin{array}{l}\text { Leopard, } \\
\text { Panthera pardus }\end{array}$ & 6 & 5 & 43 & 202 & 0 & 0 & 245 \\
\hline $\begin{array}{l}\text { Yellow mongoose, } \\
\text { Cynictis penicillata }\end{array}$ & 80 & 3 & 11 & 0 & 0 & 0 & 11 \\
\hline $\begin{array}{l}\text { White-tailed mongoose, } \\
\text { Ichneumia albicauda }\end{array}$ & 2 & 2 & 7 & 0 & 0 & 0 & 7 \\
\hline $\begin{array}{l}\text { Banded mongoose, } \\
\text { Mungos mungo }\end{array}$ & 2 & 1 & 7 & 0 & 0 & 0 & 7 \\
\hline $\begin{array}{l}\text { Spotted hyaena, } \\
\text { Crocuta crocuta }\end{array}$ & 10 & 2 & 0 & 15 & 0 & 0 & 15 \\
\hline Aardwolf, Proteles cristatus & 1 & 1 & 27 & 0 & 0 & 0 & 27 \\
\hline Civet cat, Civettictis civetta & 7 & 6 & 16 & 46 & 0 & 0 & 62 \\
\hline $\begin{array}{l}\text { Large-spotted genet, } \\
\text { Genetta tigrina }\end{array}$ & 8 & 6 & 13 & 3 & 0 & 0 & 16 \\
\hline Total & 213 & 91 & 1914 & 545 & 0 & 0 & 2459 \\
\hline
\end{tabular}

the collection procedures had been more thorough, the converse was true (Table 6). The two horses that were examined had both been used as trails horses in the Mountain Zebra National Park, where four of 14 Cape mountain zebras and eight of 11 elands examined during the same period were infested. The cattle were examined on farms in Valley Bushveld in the Eastern Cape Province (Horak 1999) and in False Upper Karoo in south-western Free State Province (Fourie \& Horak 1990), the sheep on farms in Valley Bushveld and Eastern Province Thornveld (Horak et al. 1991a), and the goats in Valley Bushveld and in Noorsveld in the Eastern Cape Province (Horak et al. 1991d; 2001) and in Mixed Bushveld in Limpopo Province (Boomker et al. 1994). The prevalence and intensity of infestation was greater on cattle and sheep than on goats, while the intensity of infestation was greater on cattle than on sheep (Table 6).

Horak et al. (2002) noted that the comparatively small total number of only 194 collections of ticks taken from humans over four decades reflects the tendency in South Africa for individuals and healthcare personnel to discard attached specimens, and more particularly larvae, once they have been removed.

In addition, a large proportion of persons living or working in rural environments in the eastern, northeastern and northern regions of the country regard 
TABLE 5 Amblyomma marmoreum collected from large herbivores

\begin{tabular}{|c|c|c|c|c|c|c|c|}
\hline \multirow{2}{*}{ Host species } & \multirow{2}{*}{$\begin{array}{l}\text { Number } \\
\text { examined }\end{array}$} & \multirow{2}{*}{$\begin{array}{l}\text { Number } \\
\text { infested }\end{array}$} & \multicolumn{5}{|c|}{ Number of ticks collected } \\
\hline & & & Larvae & Nymphs & Males & Females & Total \\
\hline $\begin{array}{l}\text { Cape mountain zebra, } \\
\text { Equus zebra zebra } \\
\text { Warthog, Phacochoerus } \\
\text { africanus }\end{array}$ & 14 & 4 & 180 & 1 & 0 & 0 & $\begin{array}{r}181 \\
2\end{array}$ \\
\hline $\begin{array}{l}\text { Giraffe, Giraffa } \\
\text { camelopardalis } \\
\text { Impala, } \\
\text { Aepyceros melampus }\end{array}$ & 6 & 1 & 2227 & 2 & 0 & 0 & 2 \\
\hline $\begin{array}{l}\text { Black wildebeest, } \\
\text { Connochaetes gnou }\end{array}$ & 13 & 1 & 146 & 2 & 0 & 0 & 148 \\
\hline $\begin{array}{l}\text { Bontebok, Damaliscus } \\
\text { pygargus dorcas }\end{array}$ & 47 & 14 & 90 & 4 & 1 & 0 & 95 \\
\hline $\begin{array}{l}\text { Springbok, Antidorcas } \\
\text { marsupialis }\end{array}$ & 22 & 2 & 4 & 0 & 0 & 0 & 4 \\
\hline $\begin{array}{l}\text { African buffalo, } \\
\text { Syncerus caffer }\end{array}$ & 1 & 1 & 8 & 1 & 0 & 0 & 9 \\
\hline Eland, Taurotragus oryx & 11 & 8 & 167 & 0 & 0 & 0 & 167 \\
\hline $\begin{array}{l}\text { Greater kudu, Trage- } \\
\text { laphus strepsiceros }\end{array}$ & 120 & 34 & 3131 & 2 & 0 & 0 & 3133 \\
\hline $\begin{array}{l}\text { Red forest duiker, } \\
\text { Cephalophus natalensis }\end{array}$ & 23 & 12 & 40 & 8 & 0 & 0 & 48 \\
\hline Gemsbok, Oryx gazella & 26 & 15 & 457 & 13 & 0 & 0 & 470 \\
\hline $\begin{array}{l}\text { Grey rhebok, } \\
\text { Pelea capreolus }\end{array}$ & 62 & 20 & 210 & 4 & 0 & 0 & 214 \\
\hline $\begin{array}{l}\text { Reedbuck, } \\
\text { Redunca arundinum }\end{array}$ & 21 & 2 & 12 & 0 & 0 & 0 & 12 \\
\hline $\begin{array}{l}\text { Mountain reedbuck, } \\
\text { Redunca fulvorufula }\end{array}$ & 20 & 3 & 10 & 2 & 0 & 0 & 12 \\
\hline Total & 656 & 185 & 6684 & 62 & 1 & 0 & 6747 \\
\hline
\end{tabular}

tick-bite as a normal occurrence and would seldom consider retaining specimens. Thus, the eight instances of bites by $A$. marmoreum are likely to represent only a small proportion of bites on humans due to this species.

The large numbers of $A$. marmoreum larvae collected from the vegetation by drag-sampling with flannel strips implies that they quest for hosts from this vantage point. This would seem to be an unnecessary strategy if tortoises and other land-bound reptiles are their only hosts. By questing from the vegetation the larvae are unlikely to be particularly host-specific and will attach to a variety of animals, an observation supported by the present findings.
Norval (1975) stated that adult ticks attach in greater numbers around the bases of the hind-legs of tortoises, and nymphs around those of the forelegs as well as on the head and neck, while larvae are evenly distributed between the two sites. Fielden \& Rechav (1994) and Burridge, Simmons \& Allan (2000) report most adults on the upper soft-skinned parts of the hind-legs and in the hollows in front of these legs, as well as around the base and on the ventral surface of the tail. Larvae and nymphs attach mainly in soft skinned localities that are protected by the carapace, particularly the neck and upper legs (Fielden \& Rechav 1994). Uys \& Horak (2005) collected equal numbers of $A$. marmoreum larvae from the bodies and from the wings of crest- 
South African tortoise tick, Amblyomma marmoreum

TABLE 6 Amblyomma marmoreum collected from domestic animals and from humans

\begin{tabular}{|c|c|c|c|c|c|c|c|}
\hline \multirow{2}{*}{ Host species } & \multirow{2}{*}{$\begin{array}{l}\text { Number } \\
\text { examined }\end{array}$} & \multirow{2}{*}{$\begin{array}{l}\text { Number } \\
\text { infested }\end{array}$} & \multicolumn{5}{|c|}{ Number of ticks collected } \\
\hline & & & Larvae & Nymphs & Males & Females & Total \\
\hline Dogs & 915 & 8 & 2 & 13 & 0 & 0 & 15 \\
\hline Cats & 20 & 1 & 0 & 2 & 0 & 0 & 2 \\
\hline Horses & 2 & 2 & 14 & 0 & 0 & 0 & 14 \\
\hline Cattle & 58 & 32 & 1942 & 17 & 0 & 0 & 1959 \\
\hline Sheep & 175 & 81 & 1132 & 30 & 0 & 0 & 1162 \\
\hline Goats & 373 & 82 & 851 & 73 & 0 & 0 & 924 \\
\hline Humans & 194 & 7 & 2 & 3 & 3 & 0 & 8 \\
\hline Total & 1737 & 213 & 3943 & 138 & 3 & 0 & 4084 \\
\hline
\end{tabular}

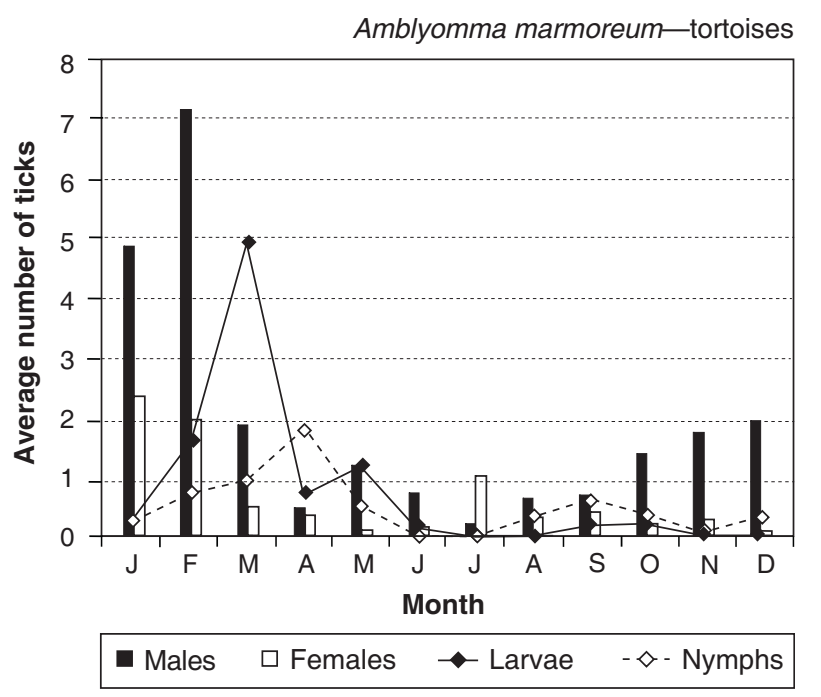

FIG. I The seasonal occurrence of Amblyomma marmoreum on tortoises in South Africa

ed francolins, fewer from their tails and the least from their heads and upper necks. They suggest that this attachment pattern might be a strategy to avoid competition with the larvae of $A$. hebraeum and Hyalomma marginatum rufipes, of which more than $84 \%$ attach to the heads and upper necks of the birds.

\section{Seasonality}

The countrywide seasonality of all stages of development of $A$. marmoreum on tortoises is graphically illustrated in Fig. 1.

Male and female ticks were most numerous on tortoises during January and February. Thereafter, with the exception of July, the only month during which female ticks outnumbered males, the numbers of female ticks remained low even when the numbers of males started to increase on tortoises from October to December. Norval (1975) recorded the largest numbers of adult ticks on leopard tortoises on a farm in the Eastern Cape Province from January to March, whereas Rechav \& Fielden (1995) recorded the largest numbers of adults on these animals in the National Zoological Gardens, Pretoria from October to January, with males most numerous from October to May and females from September to December.

Female ticks can take up to 60 days (Norval 1975) to 91 days (Fielden et al. 1992) to complete feeding on artificially infested tortoises, and Dower et al. (1988) recorded a period as long as 73 days before all females and 111 days before all males had detached from tortoises that they had collected in the field. The January and February peak in adult tick numbers may therefore reflect an accumulation of ticks that had attached a month or two earlier. The longer period of attachment of male ticks may in part explain the preponderance of male compared to female ticks on tortoises.

Larvae were most numerous on tortoises, irrespective of the localities in which they had been sampled, during March (Fig. 1), and on helmeted guineafowls and cattle in inland Valley Bushveld in the Eastern Cape Province from February to April with an April peak on the guineafowls and a March peak on the cattle (Fig. 2A and B). Larvae were most numerous on helmeted guineafowls, scrub hares and the vegetation in the Lowveld of north-eastern 
Amblyomma marmoreum - guineafowls, Eastern Cape A

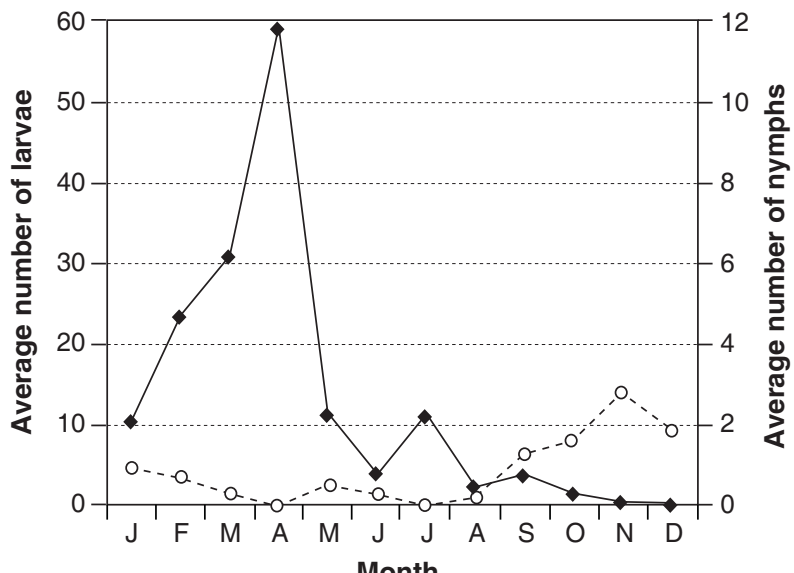

Month
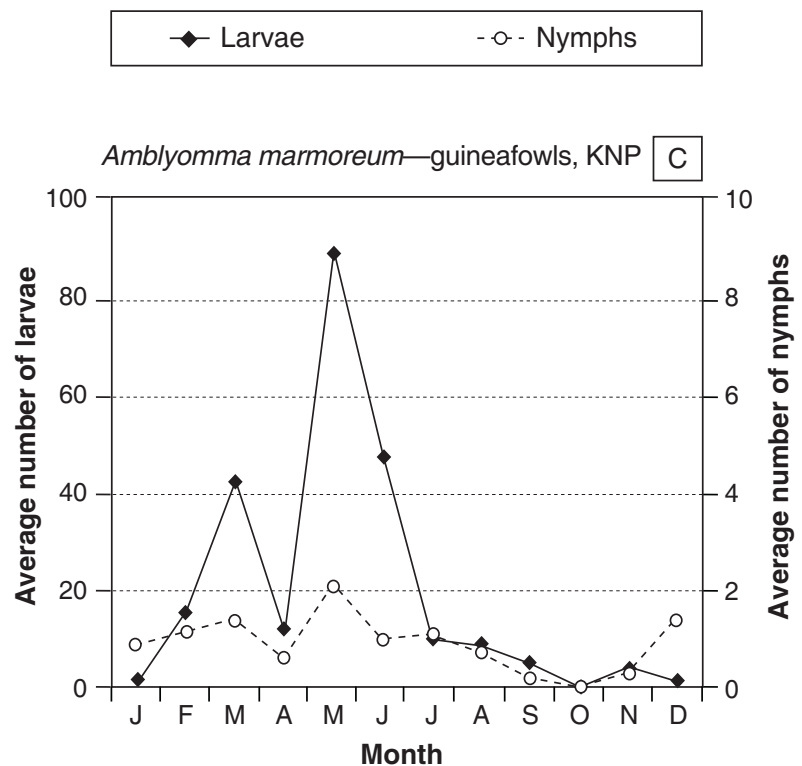

Larvae

-o- - Nymphs

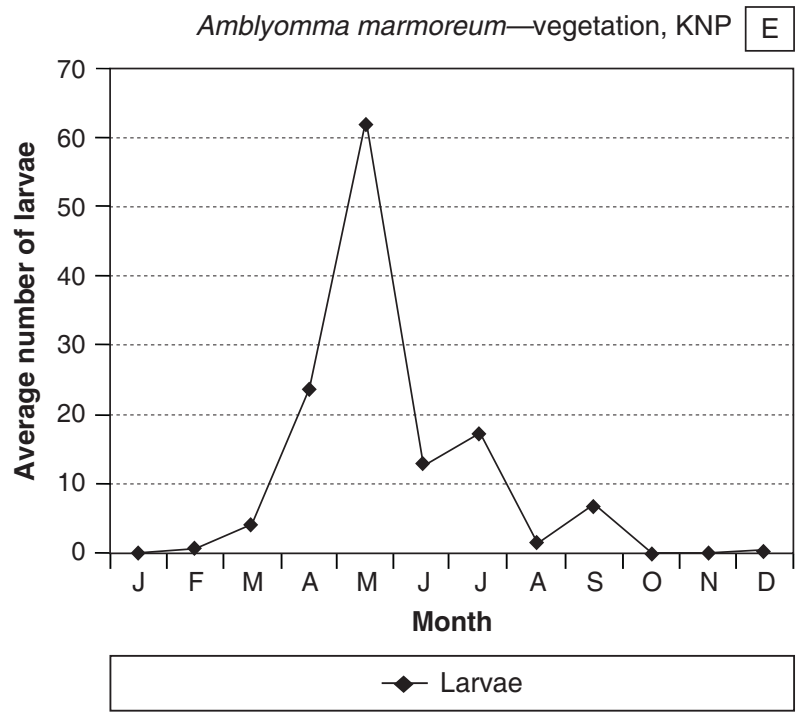

Amblyomma marmoreum — cattle, Eastern Cape B
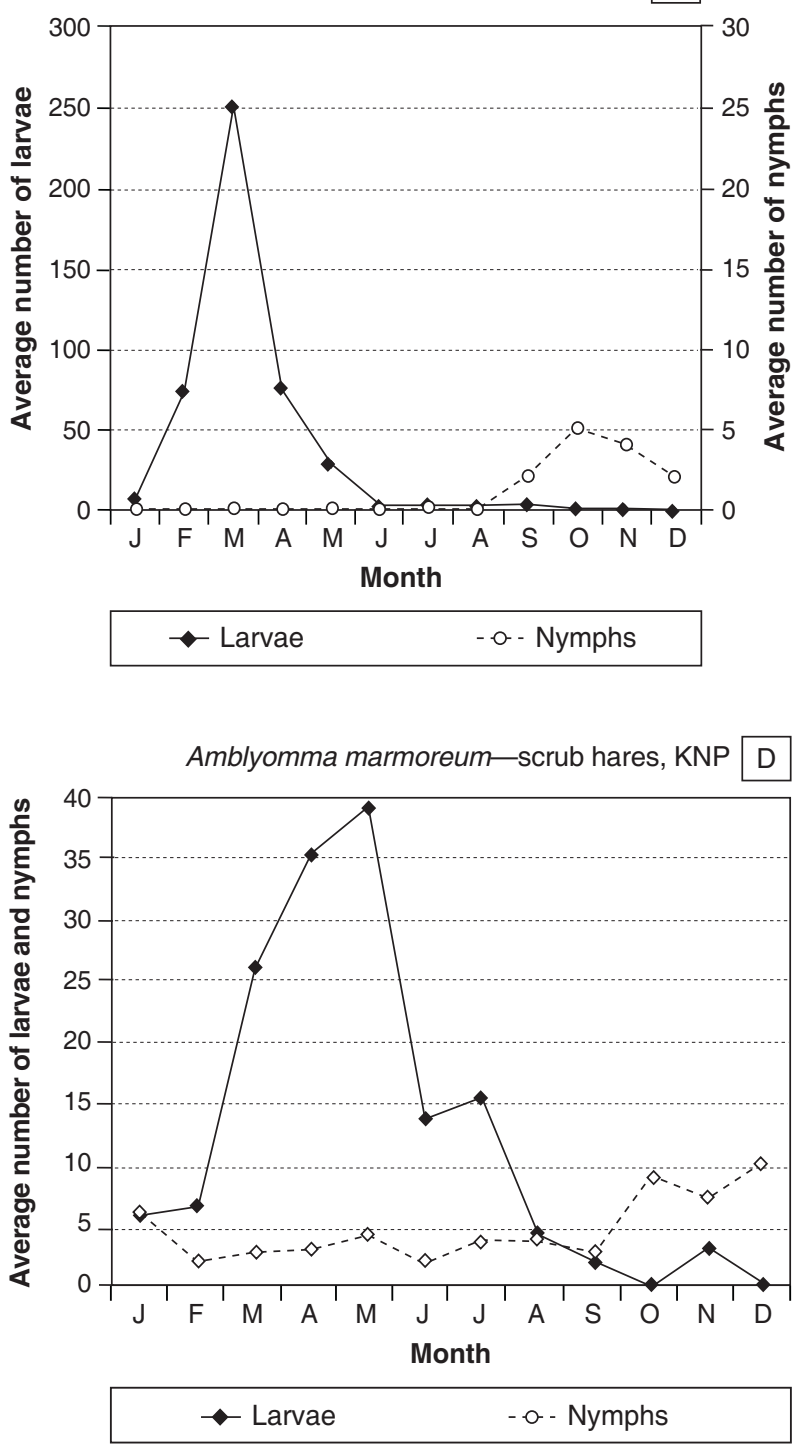

FIG. 2 The seasonal occurrence of the larvae and nymphs of Amblyomma marmoreum on (A) helmeted guineafowls and (B) domestic cattle in Valley Bushveld in the Eastern Cape Province, and (C) helmeted guineafowls, and (D) scrub hares, and of larvae on $(E)$ vegetation in the Lowveld of north-eastern Mpumalanga Province. KNP $=$ Kruger National Park 
Mpumalanga Province from March or April to June or July, with peaks in May (Fig. 2C-E). Very few if any larvae were present from October to December or January in either of the provinces. Norval (1975) collected most larvae from a naturally infested leopard tortoise during April and from the vegetation on a farm in the Eastern Cape Province from February to June with a peak in May. Rechav \& Fielden (1995) recorded the largest numbers of larvae on tortoises in the National Zoological Gardens, Pretoria from January to May with a peak in February and March.

Nymphs were most numerous on tortoises, irrespective of the localities in which they had been examined, during April (late summer) and during September (spring) (Fig. 1). Nymphs were most numerous on helmeted guineafowls and on cattle in inland Valley Bushveld from September to December (Fig. $2 A$ and $B$ ), and on scrub hares in the Lowveld from October to December (Fig. 2D). However, nymphs were most numerous on guineafowls in the latter habitat from December to August (Fig. 2C). The largest numbers of nymphs were present on tortoises in the National Zoological Gardens, Pretoria from May to October with a peak in June and July (Rechav \& Fielden 1995).

Compared to 1604 larvae, only six nymphs were collected during nearly 14 years of monthly dragsampling the vegetation in the Lowveld. These nymphs have not been incorporated in Fig. 2E. On the other hand, Norval (1975) collected 449 larvae and 27 nymphs from the vegetation by this sampling method and the latter were most numerous from October to January. The present results indicate that the seasonal pattern of occurrence of the immature stages of $A$. marmoreum in the north-east of the country is similar to that in the south-east.

Norval (1975) thought that hosts other than tortoises did not play a significant role in the life cycle or seasonality of $A$. marmoreum because of the small number of ticks he encountered on these hosts. However, the substantial numbers presently recorded on some host species, other than tortoises, as well as the proportion of these animals that are infested, imply that they may well play an important role in the tick's life cycle. In his experiments on the life cycle of $A$. marmoreum Norval (1975) found that larvae required up to 30 days to complete feeding on tortoises and nymphs up to 51 days, whereas larvae he fed on the ears of sheep engorged in 6-12 days and nymphs in 8-20 days. Dower et al. (1988) recorded a mean of 35 days and a range of 8-104 days for larvae, and a mean of 21 days and range of 4-47 days for nymphs to detach from tortoises col- lected in the field. As there was no way of knowing exactly how many days before capture these ticks attached to the latter tortoises, all these periods are probably considerably longer.

Fielden et al. (1992) compared the length of the life cycle of $A$. marmoreum on tortoises and on guinea pigs in the laboratory. On tortoises the period between larval attachment and the emergence of adults varied between 69 and 172 days, whereas on guinea pigs it varied between 63 and 95 days. Domestic chickens, and hence presumably guineafowls, have higher body temperatures than those of mammals, and larvae of $A$. hebraeum fed on chickens engorged and detached in 4-8 days compared to 5-10 days on rabbits infested at the same time (Holley \& Petney 1988). If a similar phenomenon occurs when the immature stages of $A$. marmoreum feed on guineafowls as opposed to sheep, the length of the life cycle could be reduced even further.

According to Norval (1975) the life cycle of $A$. marmoreum in the Eastern Cape Province can be completed in either 1 or 2 years. He proposed that for it to be completed in 1 year, it was necessary for larvae to feed on tortoises in late summer and the resultant nymphs and subsequent adults to feed on tortoises in spring and in early summer respectively. Fielden et al. (1992) suggest that host selection by the immature stages could be important in determining whether the life cycle is completed in 1 or in 2 years, an opinion with which we concur. Provided the larvae and the nymphs feed on mammals or birds in late summer and in spring respectively and the adults on tortoises in early summer the life cycle can be completed in 1 year.

\section{Geographic distribution}

Theiler \& Salisbury (1959) mapped the distribution of $A$. marmoreum in South Africa from the geographic coordinates of 49 localities at which collections were made. We have now added more than 100 localities to their map (Fig. 3).

Most collections have been made in the western regions of the Western and Eastern Cape and Free State provinces, and in the north-eastern regions of the Northern Cape, KwaZulu-Natal, Mpumalanga and Limpopo provinces. The seemingly large number of localities at which $A$. marmoreum was present in north-eastern Mpumalanga and Limpopo provinces are a reflection of the numerous surveys conducted in these regions by Horak and his co-workers over a period of 25 years. The several collections made in other regions imply that these are also suitable hab- 


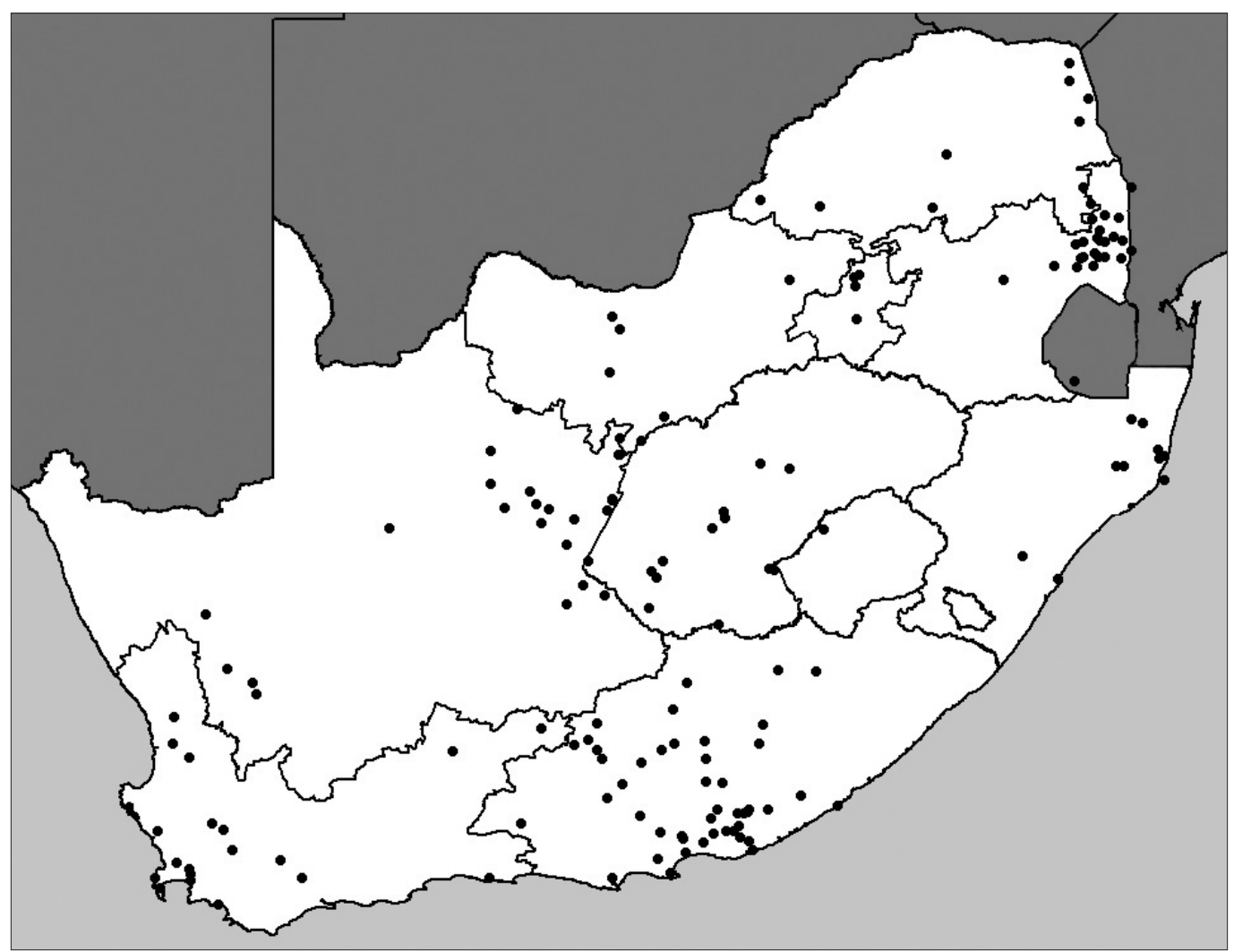

FIG. 3 The geographic distribution of Amblyomma marmoreum within the borders of South Africa

itats for the tick. Very few collections of $A$. marmoreum have been made in the eastern Highveld regions of the Eastern Cape, Free State and Mpumalanga provinces and inland mountainous regions of KwaZulu-Natal. We are, however, convinced that future collections will indicate an even wider distribution for $A$. marmoreum in South Africa than that now proposed.

\section{ACKNOWLEDGEMENTS}

We are indebted to Mr P.D. Burdett who was responsible for many of the tick collections from reptiles, and thank the South African National Parks for placing the animals as well as their staff and facilities in the various National Parks at our disposal. We gratefully acknowledge the assistance of Messrs C. Cheney, J. Sithole, M.M. Knight, E.J. Williams and the late B.D. De Klerk with processing the carcasses of the survey animals for the recovery of ectoparasites, and that of Mrs E.L. Visser, Miss M. L. Horak, Mr A.C. Uys and Mr E.J. Williams who assisted with the recovery of ticks from the processed material. Dr R. Williams of the Onderstepoort Veterinary Institute constructed the distribution map.

\section{REFERENCES}

ALLAN, S.A., SIMMONS, L.-A. \& BURRIDGE, M.J. 1998. Establishment of the tortoise tick Amblyomma marmoreum (Acari: Ixodidae) on a reptile-breeding facility in Florida. Journal of Medical Entomology, 35:621-624.

BEZUIDENHOUT, J.D. 1987. Natural transmission of heartwater. Onderstepoort Journal of Veterinary Research, 54:349-351.

BEZUIDENHOUT, J.D. 1988. Sekere aspekte van hartwateroordraging, voorkoms van die organisme in bosluise en in vitro kweking. D.V.Sc. thesis, University of Pretoria.

BOOMKER, J., HORAK, I.G. \& RAMSAY, K.A. 1994. Helminth and arthropod parasites of indigenous goats in the northern Transvaal. Onderstepoort Journal of Veterinary Research, 61:13-20.

BURRIDGE, M.J., SIMMONS, L.-A. \& ALLAN, S.A. 2000. Introduction of potential heartwater vectors and other exotic ticks into Florida on imported reptiles. Journal of Parasitology, 86: 700-704.

BURRIDGE, M.J. 2001. Ticks (Acari:Ixodidae) spread by the international trade in reptiles and their potential roles in dissemination of diseases. Bulletin of Entomological Research, 91:3-23.

BURRIDGE, M.J. \& SIMMONS, L.A. 2003. Exotic ticks introduced into the United States on imported reptiles from 1962 to 2001 and their potential roles in international dissemination of diseases. Veterinary Parasitology, 113:289-320.

DOWER, KATHY M., PETNEY, T.N. \& HORAK, I.G. 1988. The developmental success of Amblyomma hebraeum and Amblyomma marmoreum on the leopard tortoise, Geochelone 
pardalis. Onderstepoort Journal of Veterinary Research, 55: 11-13.

FIELDEN, L.J., MAGANO, S. \& RECHAV, Y. 1992. Laboratory studies on the life cycle of Amblyomma marmoreum (Acari: Ixodidae) on two different hosts. Journal of Medical Entomology, 29:750-756.

FIELDEN, L.J. \& RECHAV, Y. 1994. Attachment sites of the tick Amblyomma marmoreum on its tortoise host, Geochelone pardalis. Experimental and Applied Acarology, 18:339-349.

FOURIE, L.J. \& HORAK, I.G. 1990. Parasites of cattle in the south western Orange Free State. Journal of the South African Veterinary Association, 61:27-28.

HOLLEY, A.D. \& PETNEY, T.N. 1988. The use of domestic chickens as laboratory hosts of the larvae of the bont tick, Amblyomma hebraeum. Onderstepoort Journal of Veterinary Research, 55:75-76.

HORAK, I.G., BROWN, MOIRA R., BOOMKER, J., DE VOS, V. \& VAN ZYL, ELSA A. 1982. Helminth and arthropod parasites of blesbok, Damaliscus dorcas phillipsi, and of bontebok, Damaliscus dorcas dorcas. Onderstepoort Journal of Veterinary Research, 49:139-146.

HORAK, I.G. \& FOURIE, L.J. 1986. Parasites of domestic and wild animals in South Africa. XIX. Ixodid ticks and fleas on rock dassies (Procavia capensis) in the Mountain Zebra National Park. Onderstepoort Journal of Veterinary Research, 53:123-126.

HORAK, I.G., MACIVOR, K.M., PETNEY, T.N. \& DE VOS, V. 1987a. Some avian and mammalian hosts of Amblyomma hebraeum and Amblyomma marmoreum (Acari: Ixodidae). Onderstepoort Journal of Veterinary Research, 54:397-403.

HORAK, I.G., JACOT GUILLARMOD, AMY, MOOLMAN, L.C. \& DE VOS, V. 1987b. Parasites of domestic and wild animals in South Africa. XXII. Ixodid ticks on domestic dogs and on wild carnivores. Onderstepoort Journal of Veterinary Research, 54:573-580.

HORAK, I.G., WILLIAMS, E.J. \& VAN SCHALKWYK, P.C. 1991a. Parasites of domestic and wild animals in South Africa. XXV. Ixodid ticks on sheep in the north-eastern Orange Free State and in the eastern Cape Province. Onderstepoort Journal of Veterinary Research, 58:115-123.

HORAK, I.G., FOURIE, L.J., NOVELLIE, P.A. \& WILLIAMS, E.J. 1991b. Parasites of domestic and wild animals in South Africa. XXVI. The mosaic of ixodid tick infestations on birds and mammals in the Mountain Zebra National Park. Onderstepoort Journal of Veterinary Research, 58:125-136.

HORAK, I.G., SPICKETT, A.M., BRAACK, L.E.O. \& WILLIAMS, E.J. 1991c. Parasites of domestic and wild animals in South Africa. XXVII. Ticks on helmeted guineafowls in the eastern Cape Province and eastern Transvaal Lowveld. Onderstepoort Journal of Veterinary Research, 58:137-143.

HORAK, I.G., KNIGHT, M.M. \& WILLIAMS, E.J. 1991d. Parasites of domestic and wild animals in South Africa. XXVIII. Helminth and arthropod parasites of Angora goats and kids in Valley Bushveld. Onderstepoort Journal of Veterinary Research, 58:253-260.

HORAK, I.G. \& FOURIE, L.J. 1991. Parasites of domestic and wild animals in South Africa. XXIX. Ixodid ticks on hares in the Cape Province and on hares and red rock rabbits in the Orange Free State. Onderstepoort Journal of Veterinary Research, 58:261-270.

HORAK, I.G., BOOMKER, J., SPICKETT, A.M. \& DE VOS, V. 1992. Parasites of domestic and wild animals in South Africa. XXX. Ectoparasites of kudus in the eastern Transvaal Low- veld and the eastern Cape Province. Onderstepoort Journal of Veterinary Research, 59:259-273.

HORAK, I.G., SPICKETT, A.M., BRAACK, L.E.O. \& PENZHORN, B.L. 1993. Parasites of domestic and wild animals in South Africa. XXXII. Ixodid ticks on scrub hares in the Transvaal. Onderstepoort Journal of Veterinary Research, 60:163-174.

HORAK, I.G. \& BOOMKER, J. 1998. Parasites of domestic and wild animals in South Africa. XXXV. Ixodid ticks and bot fly larvae in the Bontebok National Park. Onderstepoort Journal of Veterinary Research, 65:205-211.

HORAK, I.G. 1999. Parasites of domestic and wild animals in South Africa. XXXVII. Ixodid ticks on cattle on Kikuyu grass pastures and in Valley Bushveld in the Eastern Cape Province. Onderstepoort Journal of Veterinary Research, 66:175184.

HORAK, I.G., BRAACK, L.E.O., FOURIE, L.J. \& WALKER, JANE B. 2000. Parasites of domestic and wild animals in South Africa. XXXVIII. Ixodid ticks collected from 23 wild carnivore species. Onderstepoort Journal of Veterinary Research, 67: 239-250.

HORAK, I.G., MACIVOR, K.M. DE F. \& GREEFF, C.J. 2001. Parasites of domestic and wild animals in South Africa. XXXIX. Helminth and arthropod parasites of Angora goats in the southern Karoo. Onderstepoort Journal of Veterinary Research, 68:27-35.

HORAK, I.G., FOURIE, L.J., HEYNE, HELOISE, WALKER, JANE B. \& NEEDHAM, G.R. 2002. Ixodid ticks feeding on humans in South Africa: with notes on preferred hosts, geographic distribution, seasonal occurrence and transmission of pathogens. Experimental and Applied Acarology, 27:113136.

HORAK, I.G., GALLIVAN, G.J., BRAACK, L.E.O., BOOMKER, J. \& DE VOS, V. 2003. Parasites of domestic and wild animals in South Africa. XLI. Arthropod parasites of impalas (Aepyceros melampus) in the Kruger National Park. Onderstepoort Journal of Veterinary Research, 70:131-163.

HORAK, I.G. \& MATTHEE, SONJA 2003. Parasites of domestic and wild animals in South Africa. XLIII. Ixodid ticks of domestic dogs and cats in the Western Cape Province. Onderstepoort Journal of Veterinary Research, 70:187-195.

NORVAL, R.A.I. 1975. Studies on the ecology of Amblyomma marmoreum Koch 1844 (Acarina: Ixodidae). Journal of Parasitology, 61:737-742.

NORVAL, R.A.I. 1983. The ticks of Zimbabwe. VII. The genus Amblyomma. Zimbabwe Veterinary Journal, 14:292-305.

OBEREM, P.T. \& BEZUIDENHOUT, J.D. 1987. Heartwater in hosts other than domestic ruminants. Onderstepoort Journal of Veterinary Research, 54:271-275.

PETER, T.F., BURRIDGE, M.J. \& MAHAN, S.M. 2000. Competence of the African tortoise tick Amblyomma marmoreum (Acari: Ixodidae), as a vector of the agent of heartwater (Cowdria ruminantium). Journal of Parasitology, 86:438441.

PETNEY, T.N., HORAK, I.G., HOWELL, D.J. \& MEYER, S. 2004. Striped mice, Rhabdomys pumilio, and other murid rodents as hosts for immature ixodid ticks. Onderstepoort Journal of Veterinary Research, 71:313-318.

RECHAV, Y. \& FIELDEN, L.J. 1995. Seasonal abundance of the tortoise tick Amblyomma marmoreum (Acari: Ixodidae) on the leopard tortoise. Journal of Medical Entomology, 32:161165.

SPICKETT, A.M., HORAK, I.G., VAN NIEKERK, ANDREA \& BRAACK, L.E.O. 1992. The effect of veld-burning on the seasonal abundance of free-living ixodid ticks as determined 
by drag-sampling. Onderstepoort Journal of Veterinary Research, 59:285-292.

THEILER, GERTRUD 1943. Ticks in the South African Zoological Survey Collection. Part II. Onderstepoort Journal of Veterinary Science and Animal Industry, 18:85-89.

THEILER, GERTRUD \& SALISBURY, LOIS E. 1959. Ticks in the South African Zoological Survey Collection-Part IX-"The Amblyomma marmoreum group". Onderstepoort Journal of Veterinary Research, 28:47-124.

UYS, A.C. \& HORAK, I.G. 2005. Ticks on crested francolins, Francolinus sephaena and on the vegetation on a farm in
Limpopo Province, South Africa. Onderstepoort Journal of Veterinary Research, 72:339-343.

WALKER, JANE B. \& SCHULZ, K.C.A. 1984. Records of the bont tick, Amblyomma hebraeum, from the angulate tortoise, Chersina angulata, and the leopard tortoise, Geochelone pardalis. Onderstepoort Journal of Veterinary Research, 51: 171-173.

WALKER, JANE B. \& OLWAGE, A. 1987. The tick vectors of Cowdria ruminantium (Ixodoidea, Ixodidae, genus Amblyomma) and their distribution. Onderstepoort Journal of Veterinary Research, 54:353-379. 